Article

\title{
Farmers' Perceptions of Tree Shelterbelts on Agricultural Land in Rural Kyrgyzstan
}

\author{
Daniel Ruppert ${ }^{1}$, Martin Welp ${ }^{1, *}$, Michael Spies ${ }^{1}$ and Niels Thevs ${ }^{2}$ \\ 1 Centre for Econics and Ecosystem Management, Eberswalde University for Sustainable Development, \\ Schicklerstr. 5, 16225 Eberswalde, Germany; daniel.ruppert@hnee.de (D.R.); michael.spies@hnee.de (M.S.) \\ 2 World Agroforestry Center, Central Asia Office, Bishkek 720001, Kyrgyzstan; n.thevs@cgiar.org \\ * Correspondence: martin.welp@hnee.de
}

Received: 6 December 2019; Accepted: 30 January 2020; Published: 4 February 2020

check for updates

\begin{abstract}
The reestablishment of agroforestry systems in Central Asia, combining crop production with protective tree shelterbelts, provides significant potential to improve farming systems. This includes increasing crop yields, additional income from timber, as well as reducing soil degradation and wind erosion. Thus, adopting shelterbelts as a form of pro-environmental behavior provides a number of socio-economic benefits, although some trade-offs need to be considered as well. This paper investigates factors that shape the perception of-and attitude towards-the establishment of tree shelterbelts by farmers in two case study regions in Kyrgyzstan. Applying a conceptual framework distinguishing between extrinsic and intrinsic factors, research methods included semi-structured interviews with farmers and local policy makers. The results show spatial differences in the perception of shelterbelts, both on the regional and on the village scale. In general, shelterbelts were negatively perceived by more than half of the farmers. The main concern raised by farmers was the shading of crops by shelterbelts, resulting in a decrease of yield. In addition, small field sizes and potential conflicts with neighbors were key concerns. Furthermore, rules set by local self-government bodies were inconsistent with the legislative framework, posing significant restrictions to the adoption of sustainable land use practices.
\end{abstract}

Keywords: agroforestry; agriculture; Central Asia; adoption; perception; pro-environmental behavior

\section{Introduction}

Agricultural systems worldwide are subject to increasingly severe environmental problems such as soil degradation, biodiversity loss, and climate change [1-3]. To cope with these challenges, many scholars call for a paradigm shift towards more sustainable land use approaches such as conservation agriculture [4], agroecology [5], or agroforestry [6,7]. While this shift requires major changes in agricultural policies and action addressing multiple levels of scale, there is also a need to better understand the situation on the ground, as any change towards more sustainable agricultural systems depends on the willingness - and capabilities—of farmers to change their practices. While much research has been conducted on the adoption of 'modern' agricultural innovations such as Green Revolution technologies [8-10], there is a shift in the adoption literature towards more sustainable practices like conservation agriculture, organic farming, and agroforestry $[7,11-13]$. The adoption of sustainable practices can be understood as a form of pro-environmental behavior, with individuals more or less consciously choosing actions that do less harm to the natural environment. The motivation for farmers' pro-environmental behavior can be manifold, as environmental and socio-economic benefits are often closely linked.

Focusing on two case studies in rural Kyrgyzstan, we investigated the factors shaping the adoption of protective tree shelterbelts, the most prominent form of agroforestry in irrigated agriculture in Central 
Asia that has a significant potential to improve land use systems in this semi-arid environment [14-16]. Tree shelterbelts along the boundaries of agricultural cropland provide a number of regulating ecosystem services (ESS), such as the reduction of wind erosion and associated soil degradation, the regulation of microclimate, and the improvement of water use efficiency due to reduced wind speeds. These services result in an increase in crop yields and make farming systems more resilient to the impacts of climate change. Moreover, when properly managed, the trees can also provide provisioning ESS as a reliable source of timber and fuel wood, offering new sources of income to farmers. Fuel wood from shelterbelts can reduce pressure on natural forests [14,17-19]. In the former Soviet Union, shelterbelts were widely adopted to reduce wind speed on large agricultural areas of collective farms (kolkhoz and sovkhoz). In the mid and late 1990s, after the collapse of Soviet Union, countries in Central Asia faced serious energy crises, with the result that tree shelterbelts were cut down for fuel wood [14,20]. However, the adoption of such practices depends on the perception and willingness of local land users, and little is known about farmers' perspectives on agroforestry practices in Central Asia so far, in particular shelterbelts. The factors that are relevant for the adoption of agroforestry vary in each Central Asian state, with governments taking different development pathways with different agricultural reforms after the collapse of the Soviet Union [21,22]. Based on field research conducted in September to October 2018 in two different regions of rural Kyrgyzstan (Issyk Kul and Jalal Abad), this article aims to address this gap for Kyrgyzstan.

To gain a holistic understanding of the manifold factors shaping local adoption processes with regard to agroforestry, we chose an analytical framework developed by Meijer et al. [23]. This framework highlights both extrinsic (e.g., geographical and socioeconomic factors) and intrinsic (individual knowledge, perceptions, and attitudes) factors, as well as their interrelations (see Section 3). The main research question is: How do extrinsic and intrinsic factors influence the adoption of shelterbelts by farmers in rural Kyrgyzstan?

Furthermore, the following sub-questions were addressed: 1 . What are differences on a regional or village level concerning the factors affecting the adoption of shelterbelts? 2. What kind of rules are set by the local self-governance body regarding the establishment of shelterbelts on agricultural cropland, and 3. How do these rules translate into decisions by the households in the sample villages?

\section{Farming Systems in Rural Kyrgyzstan: Introduction to the Case Study Area}

The Kyrgyz Republic, located in Central Asia and bordering Kazakhstan, Uzbekistan, Tajikistan, and China is a small mountainous country with a territory of $199,900 \mathrm{~km}^{2}$. Of the population of 6.4 million people, about two thirds live in villages in rural areas [24]. Even though the contribution of agriculture to the national GDP has dropped sharply from $43.9 \%$ in 1996 to only $15.9 \%$ in 2015 , the sector still accounts for around $29 \%$ of the country's employment [25]. Nevertheless, people who live in rural areas and are employed in other sectors often perform subsistence farming in addition to their off-farm jobs. In this context, agriculture is important for most of the $66 \%$ of Kyrgyz people living in rural areas to sustain their livelihood and to ensure food security [26].

Of the overall territory of Kyrgyzstan, only $6 \%$ is suitable for arable farming [27]. Due to the semi-arid to arid climate in Central Asia, arable land largely depends on irrigation techniques to perform agriculture. Most irrigation systems were set up and planned for large scale centralized farms during Soviet Union times and do not correspond to the needs of the small individual farm plots found in Kyrgyzstan today [28]. After the dissolution of the Soviet Union, the Kyrgyz Republic introduced reforms to shift from a centrally planned to a market-oriented economy. In the agricultural sector, this resulted in a restructuring of the farming sector that shifted from large scale state owned farms, with areas of crop land exceeding $2000 \mathrm{ha}$, to predominantly small scale individual land plots [29]. In the course of the redistribution of farmland from former kolkhoz to individual farmers (i.e., the former kolkhoz members), the average size of an individual farm substantially decreased from 15 ha in 1994 to 1996 to approximately 3 ha in 2002 and further to 2 ha in 2017 [25,30]. Figures 1 and 2 exemplify this process for two villages from the study regions in Kyrgyzstan. 


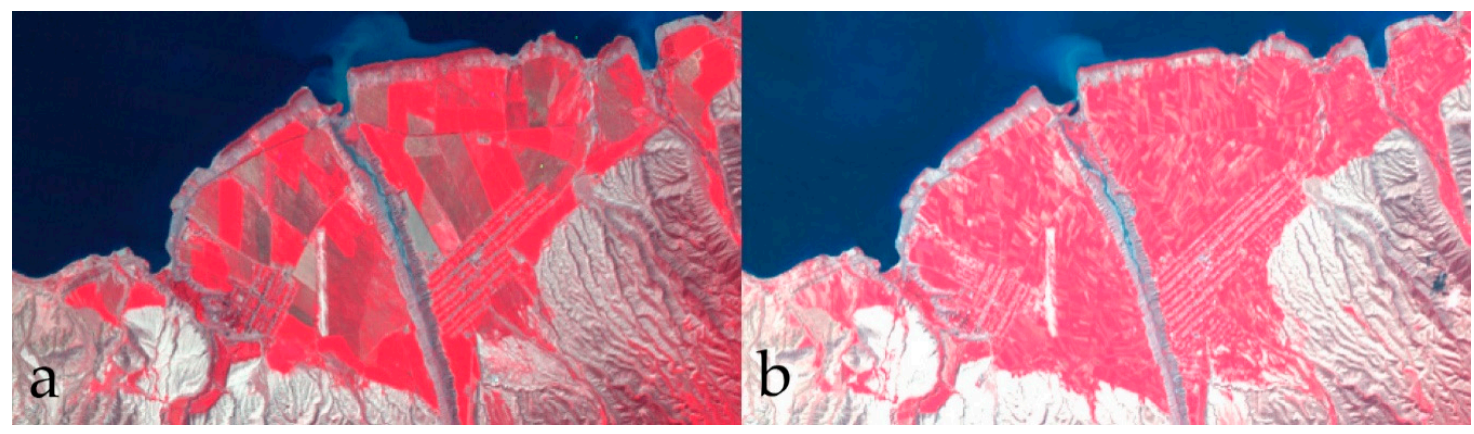

Figure 1. Changes in cropland in Barskoon, Issyk Kul, from 1990 to 2018. Left (a): Landsat TM5 image from 7 August 1990, right (b): Landsat OLI 8 image from 20 August 2018.

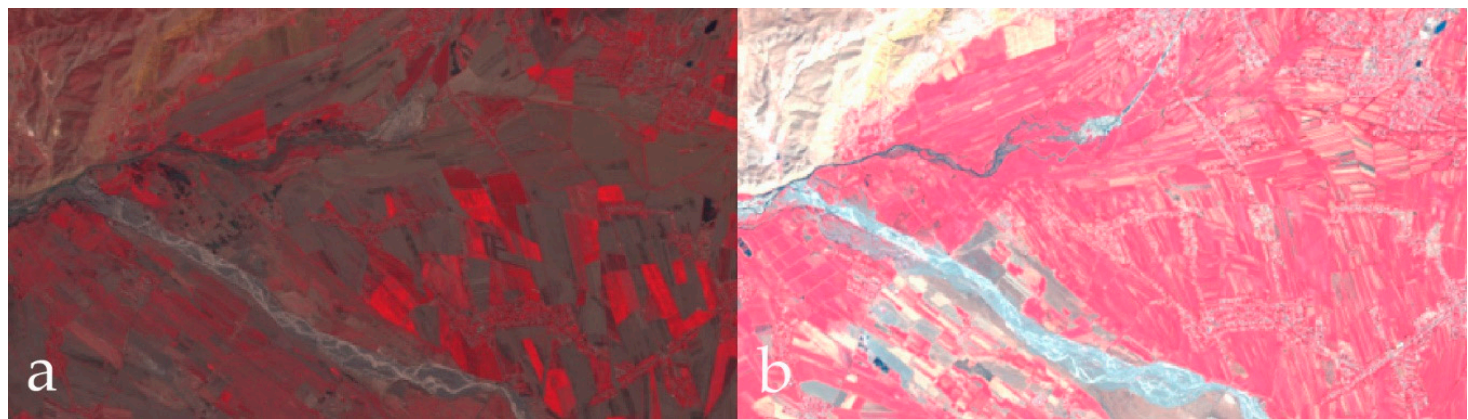

Figure 2. Changes in cropland in Suzak, Jalal Abad, from 1989 to 2018. Left (a): Landsat TM5 image from 30 May 1989, right (b): Landsat OLI 8 image from 3 September 2018.

\subsection{Study Area Issyk Kul}

The Issyk Kul region is located in the eastern part of the country and covers an area of $43,735 \mathrm{~km}^{2}$, equalling $21.8 \%$ of the total area of the Kyrgyz Republic [31]. Of this area, 22,080 $\mathrm{km}^{2}$ is occupied by the Basin of the Issyk Kul lake and $6236 \mathrm{~km}^{2}$ by the lake itself, the second largest saline lake of the world [32]. The region has a continental climate with average temperatures ranging from -7 to -15 degrees in the coldest winter months (December to February) and 11 to 20 degrees in summer (June to August) (own calculation based on the data of six climate measuring stations in the Issyk Kul Oblast from weatherbase.com). However, the climate is highly variable, from being warm, dry, and temperate in the west of the lake to slightly moist in the eastern parts [33]. The annual precipitation ranges between $132.1 \mathrm{~mm}$ in the northwest (Balychy) to $422.7 \mathrm{~mm}$ in the east (Tyup) of the Issyk Kul Oblast (data from weatherbase.com). In regards to the impact of natural hazards, the Issyk Kul region is mostly affected by hurricane winds [34]. Overgrazing, and a decrease of species diversity are among the most pressing environmental challenges, followed by droughts and the loss of soil fertility. According to a study published in 2010 by the Food and Agriculture Organization of the United Nations (FAO), $41 \%$ of the territory of the region (excluding forestry land) is facing environmental problems [31]. The selected sample villages in Issyk Kul are located on an elevation between 1600 to 1800 meters above sea level (source: Global Multi-resolution Terrain Elevation Data 2010). The population of the Issyk Kul region is 489,800 [35] with a population density of 11.2 people per $\mathrm{km}^{2}$ (based on our own calculation-dividing the population through areas). On a municipal level, several villages are subordinated to one Aiyldyk Aimak which can be translated to "village community". The sample villages Kichi-Oryuktyu and Kyurmentyu are subordinated to the Aiyldyk Aimak Kuturgu and were located in the district Tyup. The village Barskoon in the district Jeti-Oguz belongs to the Aiyldyk Aimak Barskoon, and the villages Tong and Bokonbaevo in the district Tong belong to the Aiyldyk Aimak Tong and Bokonbaevo (Figure 3). 


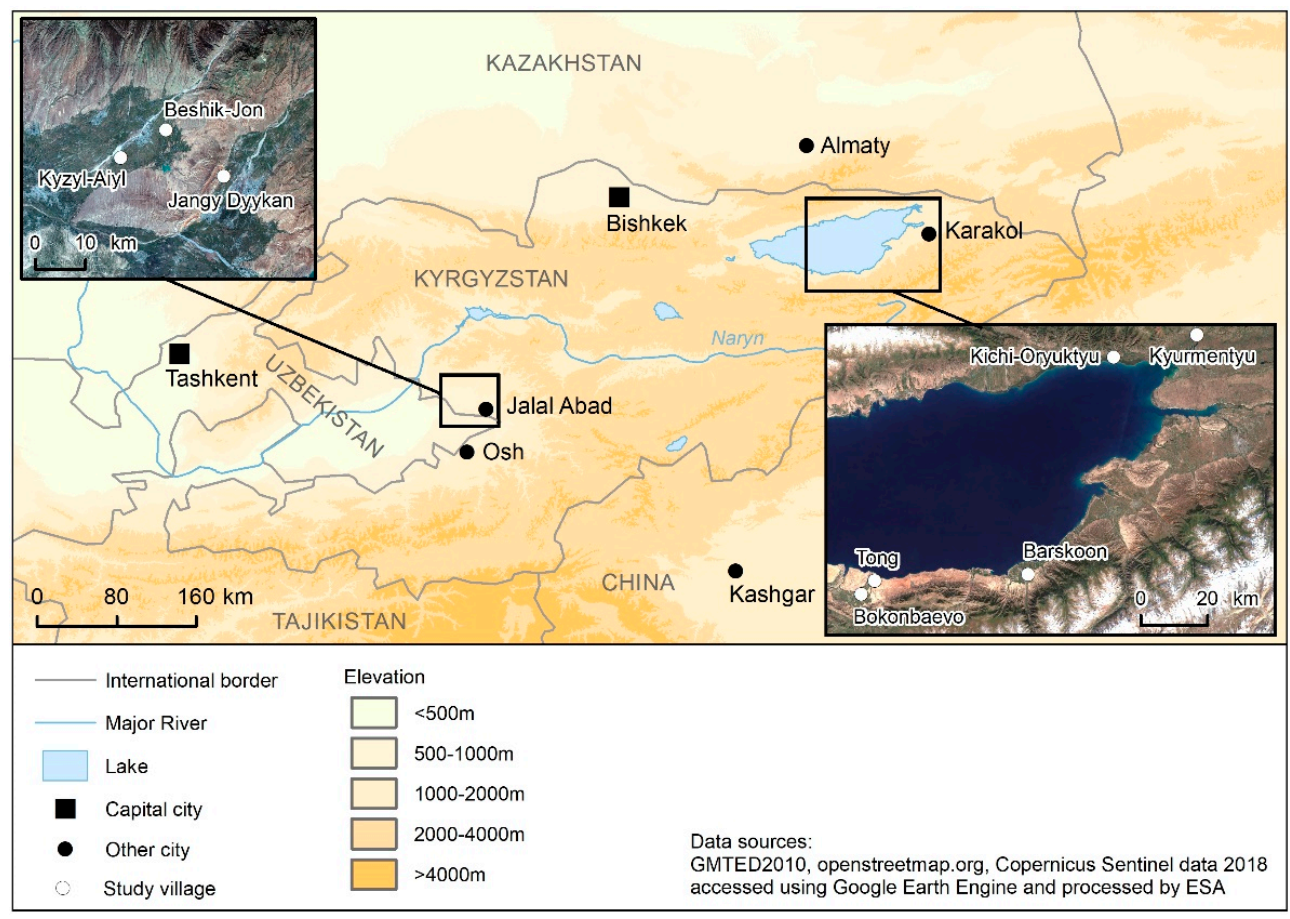

Figure 3. Location of sample villages in the regions Issyk Kul and Jalal Abad (Design: Michael Spies).

\subsection{Study Area Jalal Abad}

The second study area was the Jalal Abad region located in the southwest of the country. It covers an area of $32,418 \mathrm{~km}^{2}$, which is $16.2 \%$ of the total area of the Kyrgyz Republic [31]. The climate is highly variable and ranges from a humid hot summer continental climate to a cold semiarid climate, depending on various factors such as altitude, exposition, and relief [36]. Average temperatures range from -3.6 to -3 degrees in the coldest winter months (December to February) and from 22.4 to 25 degrees in summer (June to August). With $372.8 \mathrm{~mm}$ annually, the lowest amount of precipitation of the whole region was measured at the climate station in Tash Kumyr in the northwest of the Jalal Abad Oblast. In the city Jalal Abad, located in the south of the region, annual precipitation is $430 \mathrm{~mm}$ (data from weatherbase.com). Reasons for the environmental challenges faced in the Jalal Abad region are an over usage of natural resources, unsustainable irrigation techniques, droughts, overgrazing, and erosion. However, on a smaller scale, a wide range of further environmental problems like the loss of soil fertility and a decrease of species diversity are prevalent. According to the aforementioned study published by FAO, $71 \%$ of the land area (excluding forestry land) in the Jalal Abad region is subject to these environmental problems [31]. The sample villages in Jalal Abad are located at an elevation between 600 to 800 meters above sea level (source: Global Multi-resolution Terrain Elevation Data 2010). The population of the Jalal Abad Oblast is 1,214,400 [35]. Population density has increased in the last two decades and is currently 37.5 people per $\mathrm{km}^{2}$, increasing the scarcity of land and the pressure on natural resources. The case study village Beshik-Jon is subordinated to the Aiyldyk Aimak Beshik-Jon and the village Kyzyl Aiyl to the Aiyldyk Aimak Saydykum. Both are located in the Bazar Korgon district. The village Jangy Dyykan belongs to the Aiyldyk Aimak Suzak that is located in the district of Suzak.

\section{Conceptual Framework}

With a few exceptions $[20,22,37,38]$ both international and national research on adoption of agroforestry practices in Central Asia barely exists. There is a bulk of research from Soviet times on biophysical effects of tree wind breaks as an agroforestry system on crops [14]. As these systems were imposed down to state farms, this research does not relate to adoption. Moreover, current studies do 
not focus much on the adoption itself. Instead, those studies grasp the opinion of farmers across a wide range of topics so that adoption of agroforestry systems is only one topic among many others. As a result, no analytical framework has been tested for the Central Asian context to investigate possible factors to consider.

However, since the early 1990s, a considerable amount of adoption studies on agroforestry has been conducted in Africa and other parts of Asia [23,39,40]. Since in the 2000s, the perspective of land users is also increasingly investigated in Europe [41,42]. In Europe, major reasons why farmers refrain from applying agroforestry techniques were found to be traditions, a lack of knowledge, and a widespread assumption that conventional farming systems are easier to manage than agroforestry systems. Still, perspectives concerning agroforestry systems were highly variable throughout the European states. For example, farmers in the Mediterranean primarily valued them for increasing farm profitability, while farmers in northern Europe highlighted ecological benefits [41,42]. Studies conducted in the tropics reveal that adoption of agroforestry lacks behind the scientific and technical advances and the potential of its implementation, even though comprehensive efforts have been made to promote the integration of agroforestry into farming systems [39]. Even after successful implementation, further maintenance of agroforestry was discontinued in various cases [43,44]. Additionally, a shift of governmental agendas and legislative regulations can compromise the application of agroforestry techniques. Adoption appears to be closely linked to the provision of project incentives, with agroforestry systems being discontinued after project closure $[43,44]$. Nevertheless, there are success stories of large-scale adoptions like a documented rehabilitation of agroforestry systems in Niger on more than 7 million hectares through farmer-managed regeneration [45].

Still, the factors influencing adoption of agroforestry are not thoroughly understood and depend on a wide range of variables [23]. To identify those variables and to organize them into a framework, a meta study by Meijer et al. [23] reviews existing decision-making theories together with studies from sub-Saharan Africa that aim to identify factors that impact the uptake or the rejection of agricultural and agroforestry innovations. With some modifications, we apply this conceptual framework in our analysis of agroforestry adoption in rural Kyrgyzstan.

The meta study by Meijers et al. [23] highlights that traditional decision-making theories on innovation adoption put an emphasis on extrinsic factors like the social and economic context of the farmer and the new technology offered to them. Only within the last decade, a number of studies in and outside of sub-Saharan Africa tried to explain the adoption of agroforestry innovations by looking at intrinsic factors such as individual attitudes and perceptions. However, the comparability of adoption studies focusing on extrinsic or intrinsic factors is limited due to the variation in considered variables. In addition, factors can significantly differ from region to region due to site-specific conditions [46-48]. Meijers et al. highlight that "technology uptake is a complex nonlinear process, influenced by multiple factors" [23] (p. 43). To acknowledge the complexity of the adoption process, they developed a framework that incorporates factors suggested by existing decision-making theories like the 'diffusion of innovations theory' [49] and the 'theory of planned behavior' [50], that have guided a wide range of studies aiming to understand the uptake of agricultural innovations [51-53]. Meijers et al. integrate both extrinsic and intrinsic factors into the model to investigate the adoption of agroforestry systems. Most importantly, the interaction between those factors is highlighted. We take this framework as a guideline to identify possible intrinsic and extrinsic factors as relevant for the adoption of shelterbelts systems in Kyrgyzstan. While keeping the overall structure (Figure 4) and categories of the framework, we adapted the subcategories to the context of rural Kyrgyzstan. 


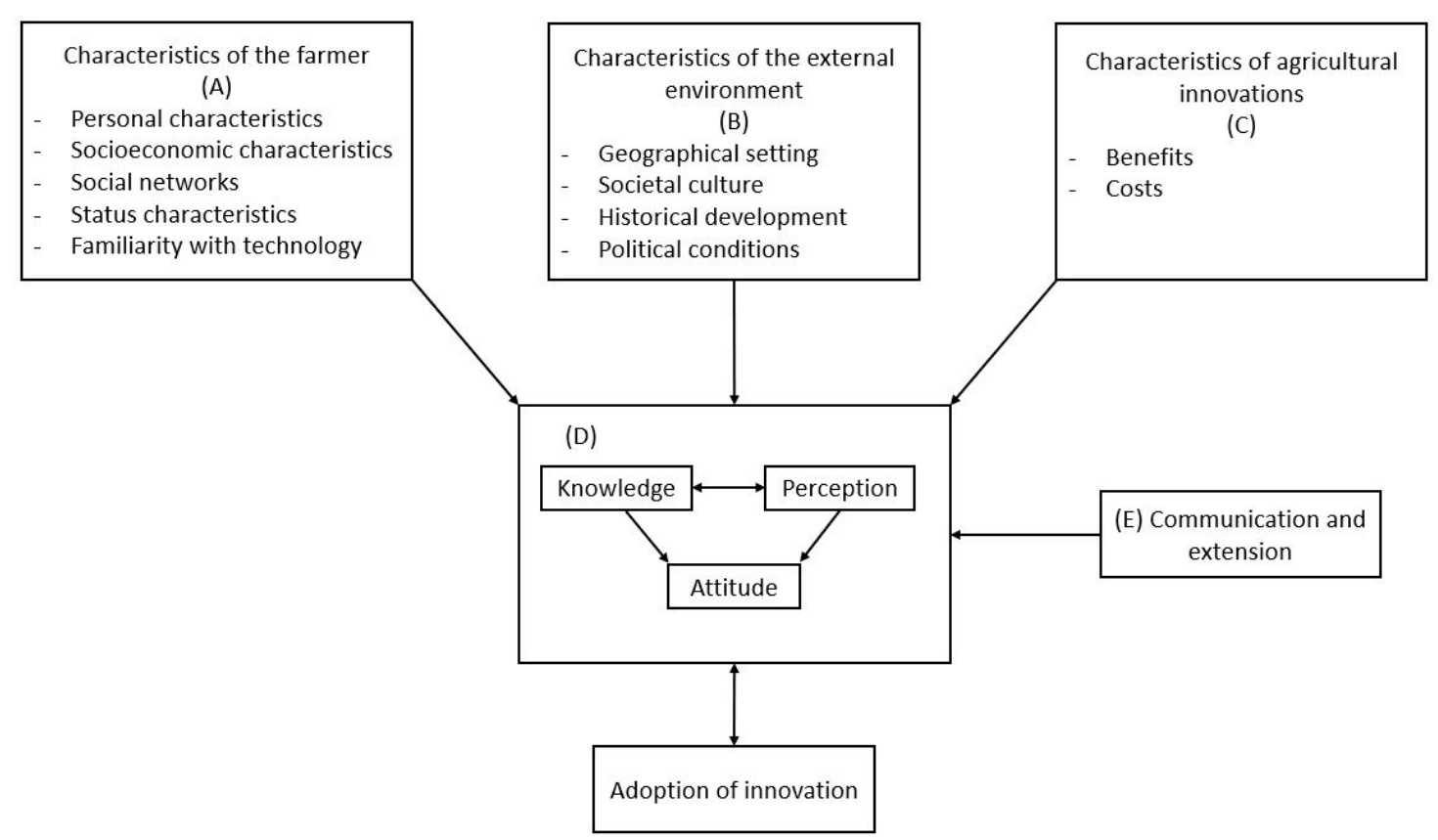

Figure 4. Conceptual framework showing the linkages and interaction between extrinsic variables $(A-C)$ and intrinsic variables (D) and the influence of the intervening variable (E) of communication and extension in the decision-making process of the adoption of agroforestry innovations (source: adaptation based on reference [23]).

In the heart of the analytical framework lies the intrinsic factors, i.e., the knowledge about and the perception of the innovation that shape the attitude towards it. A positive attitude will increase the probability of adoption, whereas a negative one will most likely result in a rejection. Knowledge refers to the factual information that someone gains about an innovation. The perception of the innovation can, but does not have to correspond with its actual impact (beneficial or detrimental), but it might be shaped by previous experience or affected by the opinion of others on the subject matter. There are three main categories of extrinsic factors that shape knowledge, perception, and attitude. First, the characteristics of the farmer: this includes personal (e.g., gender, age, ethnicity) and socioeconomic characteristics (e.g., income, assets, education). One could assume that the personal characteristics constitute intrinsic factors. However, in the context of this conceptual framework, intrinsic factors are related to psychological factors and depict inner processes that are the basis for the formation of knowledge, perceptions, and attitudes. In this context, personal characteristics might be a major determining factor for intrinsic factors, but are categorized by Meijer et al. as 'external' influencing factors. In addition, for the research it was of interest whether there are conflicts within the social network, with neighbors, or within the village community that might impact the willingness to adopt. Moreover, it was investigated whether there are rules set by the community regarding the planting of trees on fields (e.g., as shelterbelts). Familiarity with the technology refers to the actual usage of shelterbelts by themselves or in their environment.

Other extrinsic factors refer to the characteristics of the external environment, firstly the geographical setting (e.g., climate, soil conditions, and usage of irrigated or rain-fed land for agricultural purposes). In the case of Kyrgyzstan, this factor is closely interlinked with the political conditions. National policy strictly defines what types of land can be used for what purpose. Additionally, the status of land tenure shapes decisions on agroforestry systems that can only be successfully implemented with a long-term commitment. As part of the analysis of the political conditions, particular attention was paid to the local self-government body, the Aiyl Okmotu, being in charge of the respective Aiyldyk Aimak, since they are exercising control over the use of agricultural land. Furthermore, the status of farmers within the village communities was investigated. Societal aspects were of particular interest 
with regard to traditions that shape how agriculture is performed. In this context an important category that was added to the characteristics of the external environment is the historical experience. Shelterbelts are not an agroforestry innovation in Kyrgyzstan in the literal sense. As previously mentioned, the Soviet republics had a long tradition in integrating shelterbelts into farming systems. For this reason, it is important to gain an insight into how the current perception and knowledge is shaped by the historical experience. In this sense, it could be more accurate to frame shelterbelt adoption as a reintegration of shelterbelts into farming systems.

\section{Methods}

The methodological approach consisted of the following steps. First, relevant literature on agroforestry in Central Asia, general land use, land tenure, and the historical development of Kyrgyzstan were reviewed. An important aspect was to analyze the legislative framework of the country to identify those laws that regulate the planting of trees on farmland. Next, literature on agroforestry adoption was reviewed to identify relevant categories suggested by previous research to be focused on during the field research. In a third step, these categories served as a basis to develop a semi-structured household questionnaire to find out how intrinsic and extrinsic factors influence the adoption of shelterbelts by farmers in rural Kyrgyzstan. The Issyk Kul and Jalal Abad Regions were chosen as research areas, since previous research on technical aspects of agroforestry systems had been conducted there $[54,55]$. These regions reflect two different geographical areas of the country, revealing different factors, or at least a different specification of factors (e.g., in terms of climatic conditions) that affect the adoption of shelterbelts in the north and the south of the country. In the two sample regions, a total of 80 semi-structured household interviews were conducted in 8 different villages ( 5 in Issyk Kul, 3 in Jalal Abad), 10 in each village. The villages were selected based on the criteria that they belonged to different Aiyldyk Aimak to compare the position of the households towards shelterbelts with the rules set by their Aiyl Okmotu. Most of the households were selected randomly, covering different parts of the village. Households not holding any agricultural land were excluded from interviews. In the three villages in the Jalal Abad Region, snowball sampling was occasionally applied since it was difficult to approach households.

The household interviews were structured into five categories to cover extrinsic and intrinsic factors that possibly influence the adoption of shelterbelts. The categories were land tenure, land use, shelterbelts, social factors, and demographics. These categories were developed (a) from factors suggested by previous studies on agroforestry adoption and (b) from informal talks with experts as well as literature research on the reform processes in Kyrgyzstan. The questions asked during the interviews were sometimes updated or modified, as new relevant aspects were brought up during the interviews. To gain an insight into the position of the local government towards the reestablishment of shelterbelts in the villages, expert interviews were conducted with the responsible persons of the Aiyldyk Aimak in charge of the sample villages.

\section{Results}

\subsection{Household Characteristics and Local Context}

Table 1 provides an overview of the socio-demographic characteristics of the respondents in Issyk Kul and Jalal Abad. The data illustrates the high dependency of households in both regions on their agricultural output as main source of income. The main crops planted in Issyk Kul were wheat, fodder crops (e.g., barley, alfalfa), potatoes, and vegetables. In the southern part of the region, fruit trees planted on cropland were common. In Jalal Abad, cotton, grass, and corn were the main crops. All households depended on irrigation techniques for their agriculture. Agriculture and animal husbandry were closely interrelated. In addition, some respondents supplemented their income by working off-farm (e.g., as a driver, sewer, teacher or mechanical engineer). Compared to Issyk Kul, households were larger in Jalal Abad, while available land (cropland and kitchen gardens) was 
significantly smaller. Possibly as a result, in Jalal Abad more households had family members working abroad to provide support through remittances. These findings correspond to previous research on migration in the two regions [56]. In addition, the educational level was lower among respondents in Jalal Abad than in Issyk Kul. Presumably, this limited their possibilities to diversify their income. The whole sample has a gender bias towards male respondents, since men, in particular the elderly, traditionally hold the position of the head of the household. This is also reflected by the average age of respondents (see Table 1). Wood was an important energy source in both regions, used by over $90 \%$ of the households for cooking and heating. However, the main source of energy for heating was coal. Previous studies on the factors impacting the adoption of agroforestry systems found land tenure to affect adoption significantly [57,58]. Among the sample, the land tenure status reported by households was highly variable, ranging from renting agreements of 49 to 99 years. Still, half of the respondents in both regions considered the land they used as their own. This discrepancy is a surprising research outcome. In the following, a brief introduction into the privatization process of agricultural land will be given to put these findings into context. The beginning of the land distribution differed on a regional and local level since the de-collectivisation process started as early as 1992 and was only made compulsory in 1994. The total amount of land distributed in each village differed greatly, depending on the size and number of people eligible to a land share. At least in theory, land was evenly distributed among the former members of the collective farms. Land share documents were converted to ownership certificates by the State in $1998[59,60]$. However, not only interviewed farmers, but also the Aiyl Okmotu in both regions provided inconsistent information concerning the land tenure status of households. These findings illustrate a lack of communication between the central government, the Aiyl Okmotu, and rural households. Nevertheless, no connection between the perceived land tenure status of households and the willingness to adopt shelterbelts could be evidenced.

Table 1. Socio-demographic characteristics of respondents in households in Issyk Kul and Jalal Abad.

\begin{tabular}{|c|c|c|c|}
\hline Socio-Demographics & & Issyk Kul $(n=50)$ & Jalal Abad $(n=30)$ \\
\hline Average age of respondent & & $\begin{array}{l}52.5 \text { (range } 24 \text { to } \\
76 \text { years) }\end{array}$ & $\begin{array}{l}51.36 \text { (range } 22 \text { to } \\
86 \text { years) }\end{array}$ \\
\hline \multirow[t]{2}{*}{ Gender of respondent } & Male & 39 & 25 \\
\hline & Female & 11 & 5 \\
\hline Ethnicity & $\begin{array}{c}\text { Kyrgyz } \\
\text { households }\end{array}$ & $50(100 \%)$ & $25(83,33 \%)$ \\
\hline \multirow{4}{*}{ Level of education of respondent } & $\begin{array}{c}\text { Uzbek } \\
\text { households }\end{array}$ & $0(0 \%)$ & $5(16,66 \%)$ \\
\hline & Tertiary & 21 & 8 \\
\hline & Secondary & 21 & 19 \\
\hline & Vocational & 6 & 2 \\
\hline $\begin{array}{c}\text { Average number of members per } \\
\text { households }\end{array}$ & & 4.34 (range 1-8) & 5.5 (range 2-10) \\
\hline $\begin{array}{l}\text { Number of households receiving } \\
\text { remittances through migration }\end{array}$ & & 12 & 15 \\
\hline $\begin{array}{c}\text { Average number of absent (migrated) } \\
\text { household members }\end{array}$ & & 1.5 & 2 \\
\hline $\begin{array}{l}\text { Number of households with agriculture } \\
\text { as main source of income }\end{array}$ & & $42(84 \%)$ & $27(90 \%)$ \\
\hline Average size of cropland & & 1.81 hectare & 1.11 hectare \\
\hline Median size of cropland & & 1.59 hectare & 0.80 hectare \\
\hline Average size of kitchen garden & & 0.25 hectare & 0.17 hectare \\
\hline Median size of kitchen garden & & 0.17 hectare & 0.15 hectare \\
\hline
\end{tabular}




\subsection{Farmers' Perspectives on Shelterbelts}

“Crack willows from my neighbor are shading my land and the root system causes trouble. The grass doesn't grow well because of the trees. I would never plant shelterbelts. It causes a lot of conflict with neighbors"

(Interview with farmer in the village Tong in the Issyk Kul region 13.09.2018)

"It depends-With small fields more problems arise. Since it is shading both sides. In the past [during Soviet times] with big fields they had shelterbelts and it made sense. In a small field it doesn't make sense to have shelterbelts. They cause too much shadow."

(Interview with farmer in the village Kyurmentyu in the Issyk Kul region 11.09.2018)

Overall, shelterbelts did not play a prominent role in current land use systems: Only 15 out of 80 respondents (11 in Issyk Kul, 4 in Jalal Abad) had shelterbelts on their agricultural land. The main tree species were poplar (mainly Populus nigra) followed by crack willow (Salix fragilis) and elm (Ulmus minor). One reason for the low adoption rate appears to be a rather negative perception of shelterbelt systems: About $59 \%$ of respondents perceived them as overall negative and only $26 \%$ as positive, with a generally more positive opinion in Issyk Kul compared to Jalal Abad (see Figure 5). About $14 \%$ of the interviewees in Issyk Kul stated that there is a trade-off to plant shelterbelts and that it depends on the site-specific conditions (e.g., size of the land, wind, climate) whether they are beneficial or disadvantageous. In the Issyk Kul region, opinions towards shelterbelts differed greatly from village to village. In Kichi-Oryuktyu, 70\% (7) of the respondents had a negative perception of shelterbelts, while in Bokonbaevo, $80 \%$ (8 respondents) perceived them in positive terms. In the Jalal Abad region, results were more homogenous, with the majority of interviewees holding a negative perception. Nonetheless, in the village of Kyzyl Aiyl in Jalal Abad, 100\% (10 respondents) considered shelterbelts negatively, in contrast to only $40 \%$ (4 respondents) in Jangy Dyykan in the same region.

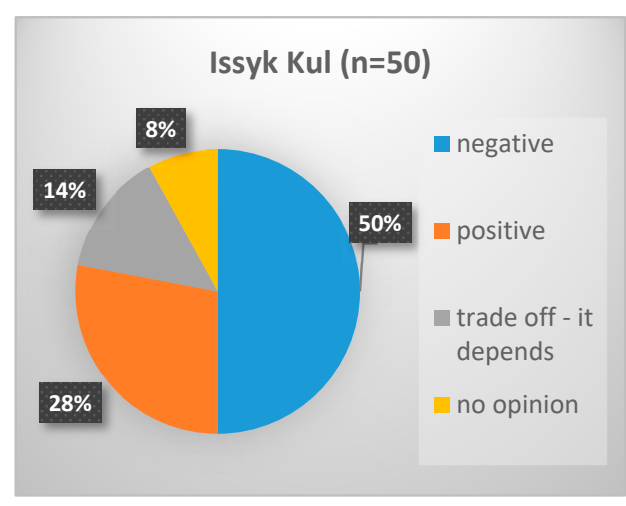

(a)

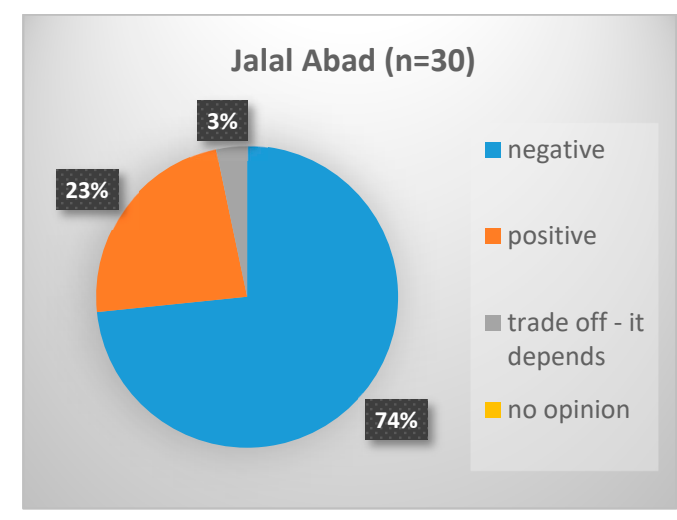

(b)

Figure 5. (a) Perception of respondents in households towards shelterbelts in the Issyk Kul region; (b) Perception of respondents in households towards shelterbelts in the Jalal Abad region. The overall perception was assessed by a first question that introduced the subject of shelterbelts during the interviews.

\subsubsection{Perceived Benefits}

Figure 6 illustrates which types of benefits are considered important by interviewees. In Issyk Kul, 14 different types of benefits and a total of 83 benefits were mentioned. In Jalal Abad, respondents named only 8 different types of benefits in a total of 22 mentions. This great disparity is not only related to the discrepancy in the number of interviewed households per region. When breaking it down to the benefits mentioned per household, the discrepancy remains (Issyk Kul: 1.66 mentioned benefits per household; Jalal Abad: 0.73 mentioned benefits per household). The number of mentioned benefits per 
household ranged from 0 to 5 . The amount of benefits named per household provides the information that although a wide range of benefits were brought up during the interviews, individual knowledge about the manifold benefits of shelterbelts seemed to be considerably low.

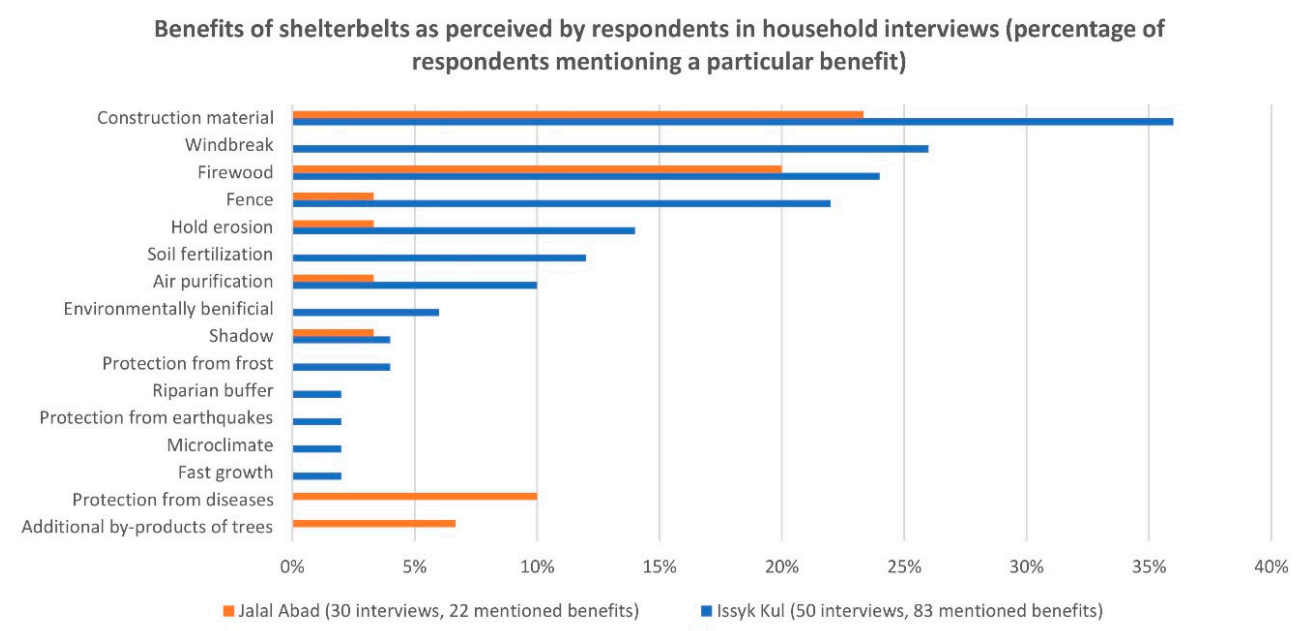

Figure 6. Type of benefits of shelterbelts mentioned by respondents in household interviews in the Issyk Kul and Jalal Abad region.

\subsubsection{Perceived Concerns}

The main concerns raised by the farmers were grouped into ten types during the analysis. In Issyk Kul (see Figure 7), 9 different types of concerns and a total of 66 concerns were mentioned. Per household, an average of 1.32 concerns were raised (ranging from 0 to 5). In the Jalal Abad Region (see Figure 7), 8 different types and a total of 43 concerns were brought up, with an average of 1.43 mentioned concerns per household (ranging from 0 to 3). The main type of concern was shading, followed in Jalal Abad by possible conflicts with neighbours and difficulties with agricultural machinery. Farmers were concerned that machineries like tractors and combine harvesters cannot move properly on the fields when facing trees as obstacles. This concern was closely linked to the small size of field plots limiting the space of the machinery to manoeuvre. Respondents often considered their fields as being too small for shelterbelt systems and refered to the large scale farms during Soviet times. As a possible solution to avoid conflicts between neighbours and to mitigate the issue of small field sizes, respondents were also asked about their openness towards cooperative arrangements (see Section 4 below).

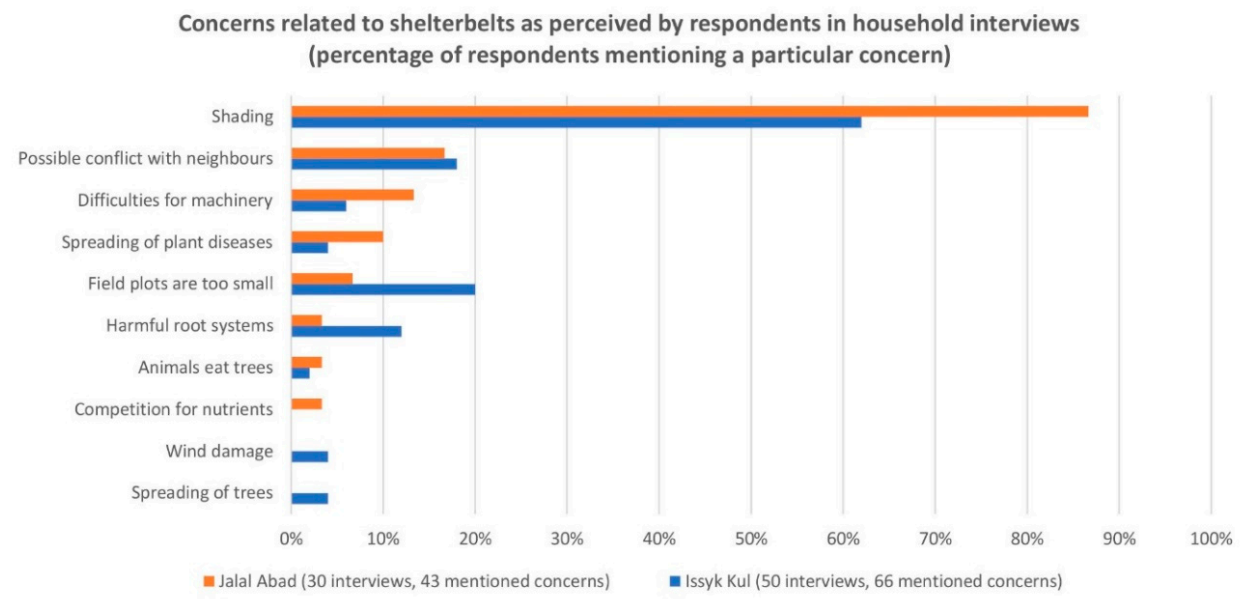

Figure 7. Types of concerns regarding shelterbelts as mentioned by respondents in household interviews in the Issyk Kul and Jalal Abad region. 


\subsection{Shelterbelts and Trees on Fields-Permissions and Restrictions}

\subsubsection{The Legal Status for Establishing Shelterbelt Systems}

All land areas of the Kyrgyz Republic are assigned to a certain category that determines their purpose along with a particular set of rules regulating their management (Article 10 of the law no. 45 Land Code of the Kyrgyz Republic). Agroforestry is only marginally acknowledged in the legislative framework of the Kyrgyz Republic. Nevertheless, the definition for what agricultural land can be used for (Article 73 of the law no. 45 Land Code of the Kyrgyz Republic, Article 1 of the law no. 4 on the management of agricultural land) contains the term 'protective afforestation' that refers to shelterbelts and allows, by definition, the planting of shelterbelts on the edges of agricultural land.

\subsubsection{Perceptions and Rule-Setting by the Aiyl Okmotu}

The rules set by the Aiyl Okmotu, the executive body of local self-governance that exercises control over the use of agricultural land in the territorial administration (law no. 101 on local selfgovernment), differ between the two study regions as well as between the villages within each region, despite the fact that the same laws concerning the planting of shelterbelts is applicable for the whole country (law no. 45 Land Code of the Kyrgyz Republic, law no. 4 on the management of agricultural land). Figure 8 illustrates the different regulations regarding the planting of shelterbelts as defined by the investigated Aiyl Okmotu in Issyk Kul and Jalal Abad. The symbols for fruit and forest trees refer to the type of trees to be used as shelterbelts.

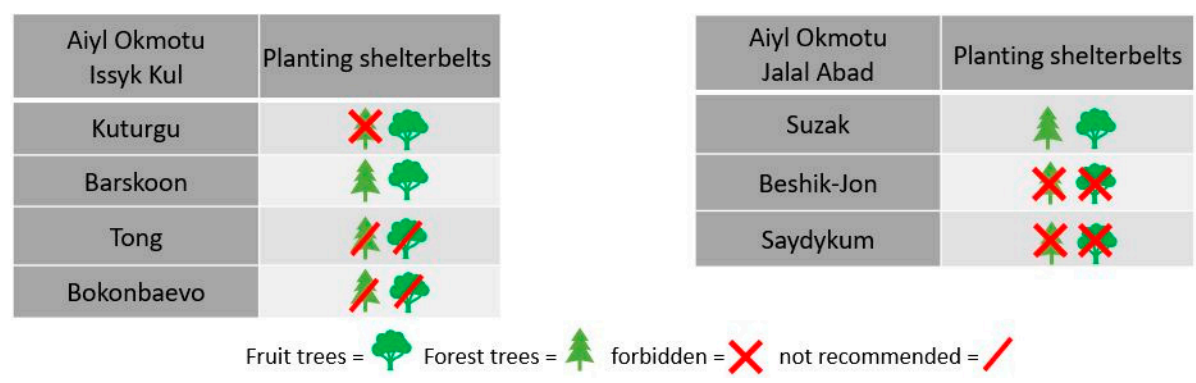

Figure 8. Rules set by the Aiyl Okmotu in Issyk Kul and Jalal Abad concerning the planting of shelterbelts on agricultural land (Source: Interviews with 8 Aiyl Okmotu heads).

In two Aiyldyk Aimak in Issyk Kul, Tong and Bokonbaevo, farmers were allowed to plant shelterbelts, but the practice was discouraged by the local authorities. The Aiyl Okmotu were comparing the current size of field plots owned by household with the size of fields during the Soviet era and considered the current field sizes to be too small to make effective use of shelterbelts. From their point of view, the shading of plants by the trees would outbalance the sheltering effect. In addition, they argued that the root system of shelterbelts planted on the edges of agricultural cropland would make tillage difficult. In Kuturgu, Barskoon, and Suzak, planting shelterbelts was only allowed under certain conditions and with some restrictions. In Kuturgu, only the planting of bushes or small fruit trees was allowed as shelterbelts, while poplars were explicitly forbidden. In Barskoon, the planting of shelterbelts was generally allowed. Nevertheless, households had to negotiate with their neighbors if they could plant them. If the shelterbelts hindered the machinery to maneuver, the Aiyl Okmotu demanded from farmers to root the trees out. In Suzak, the planting of shelterbelts was generally allowed, although farmers needed to formally ask the Aiyl Okmotu first. In Beshik-Jon and Saydikum, shelterbelts were handled most restrictively by the Aiyl Okmotu, who referred to an ostensible law that generally forbids the planting of shelterbelts. However, our research revealed that no such law exists. Comparing the results between the two regions, it can be seen that shelterbelts are dealt with more restrictively in Jalal Abad. However, even though local rules in Issyk Kul are not as strict as in Jalal Abad, most Aiyl Okmotu recommended not to plant shelterbelts. The main concern of Aiyl 
Okmotu was related to the shading effect of trees on crop land and its potential source of conflict between farmers. The position of the households in Jalal Abad towards shelterbelts tend to reflect the rules set by their Aiyl Okmotu. In Issyk Kul, though, deviation on a village level existed. Particularly outstanding were the results of the village Bokonbaevo, that will be introduced in the discussion.

\section{Discussion}

The purpose of this study was to identify extrinsic and intrinsic factors that influence the adoption of shelterbelts by farmers in rural Kyrgyzstan. The results of the interviews with the households and Aiyl Okmotu revealed that the adoption of shelterbelts among the sample was considerably low. Moreover, only one respondent in the whole sample expressed an intention to plant shelterbelts. Despite the low adoption rate by households, respondents were still able to provide information about their perception of the benefits and concerns associated with shelterbelts. These perceptions were partly rooted in witnessing the large-scale application of this agroforestry system during Soviet times. This experience in the past was one of the main reasons why interviewees considered their crop lands as too small to make effective use of shelterbelts. Overall, shelterbelts were perceived negatively by a large percentage of the respondents. This was particularly the case in Jalal Abad region. The results of the research partly confirmed the reservation of the rural population regarding the integration of trees into their farming systems as revealed by previous research in Kyrgyzstan and the neighboring countries Tajikistan and Uzbekistan $[20,38,61]$. However, the negative perception by a great share of the interviewees was mostly limited to shelterbelts and did not necessarily mean that households were generally opposed to the idea of planting trees on crop land.

During the research, relevant extrinsic factors impacting the perception and adoption of shelterbelts were identified, such as the current size of the crop lands, the geographical setting and climatic conditions, the experience with shelterbelt systems during Soviet times, and the rules defined by the Aiyl Okmotu regarding the planting of shelterbelts on crop lands. These extrinsic factors influenced the intrinsic factors, e.g., the factual knowledge of and the perceived benefits and concerns about shelterbelts. Furthermore, this research revealed a profound gap between the rules set in the legislative framework regarding shelterbelts on the one hand, and their interpretation and implementation by the local Aiyl Okmotu on the other hand. In addition, the key demographic data highlighted differences of the socio-economic status of the households on a regional level, e.g., the size of land owned and level of education. Different factors affecting the adoption in the two research areas and some arguments for or against shelterbelts were weighed differently, highlighting the role of site-specific conditions for the farmers' perceptions. The absence of trainings and extension services promoting shelterbelts possibly hampers the reintroduction of shelterbelts in both regions.

As a means to solve the issue of small individual field plots, cooperative agreements to jointly fence neighboring agricultural fields with a larger shelterbelt system were discussed with respondents in both regions. Such arrangements with shared benefits and losses could also reduce the potential for conflicts among farmers. The discussions revealed that overall, more households in Issyk Kul than in Jalal Abad were open to work in a cooperative. Generally, local views on cooperative arrangements are largely shaped by an idealization of heavily subsidized cooperatives during Soviet times on the one hand, and a failure of post-Soviet cooperatives in the 1990s due to a lack of sufficient agricultural inputs and unrealistic expectations for individual economic benefits on the other hand. Several respondents also mentioned a high degree of mistrust between farmers as an obstacle to motivate people to cooperate. Nevertheless, the Aiyl Okmotu in both regions were indicating support for the set-up of cooperatives (e.g., by providing cheap loans). In this context, supporting best practice examples of cooperatives might be a viable option. The discussions also showed that positive experiences with cooperation was an important factor for the willingness of individual households to join a cooperative.

In contrast to suggestions by previous research from Uzbekistan, Kyrgyzstan, and Kazakhstan, the water consumption of trees or shelterbelts was not raised as a concern by respondents $[14,17,37]$. Nevertheless, in the sample villages agriculture was highly dependent on irrigation and one quarter of 
the respondents reported difficulties with their water access. To illustrate the interlinkages of extrinsic and intrinsic factors affecting the adoption of shelterbelts on a village level, two examples are discussed in the following. The village Bokonbaevo located in Issyk Kul serves as an example for circumstances that increase the chances of shelterbelt adoption, whereas the village Kyzyl Aiyl in the Jalal Abad region illustrates the opposite.

In Bokonbaevo, the largest number of interviewed households (5 of 10) had planted shelterbelts, and more households than in other villages had a positive perception towards shelterbelts (8 of 10). In addition, respondents in Bokonbaevo mentioned a high number of benefits (24) and the lowest number of concerns (7) among all sample villages. The benefits brought up by respondents reflected their needs and were largely related to the climatic conditions of the area. Interviewees reported strong winds in the area and a lower level of precipitation compared to the sample villages in Jalal Abad. This information was also supported by the climate data of the nearest climate station in Kadhzi-Say (data retrieved from weatherbase.com). In this context, respondents emphasized the function of shelterbelts to act as a windbreak and their capability to keep the soil moist through reduced evapotranspiration. In addition, shelterbelts acted as fences to prevent freely grazing animals from entering the agricultural cropland. Interestingly, those positive effects were remembered and traced back by respondents to the Soviet era. Even though the Aiyl Okmotu in Bokonbaevo had reservations towards shelterbelts and did not recommend planting them, all households specifically asked about regulations (8 of 8) acknowledged no official restrictions and argued that they are free to plant shelterbelts. In addition, no current or anticipated conflicts with neighbors in relation to shelterbelts were reported.

In contrast, only 1 of 10 households in Kyzyl Aiyl reported to have a 'shelterbelt' on crop land. The shelterbelt was solely planted to provide firewood and construction material and not with the intention to provide protection for the crops. Kyzyl Aiyl was one of the villages where most types (6) and the highest number of concerns (18) were reported. This was reflected in the overall negative perception of shelterbelts in the village (10/10). Only two types of benefits were brought up by respondents: the provision of construction material and firewood. Respondents emphasized the negative impacts of shelterbelts and stated that planting them was a trade-off to receive timber. The key effect of a shelterbelt to act as windbreak was not mentioned or even known by households. In addition, the climate data reported a lower wind speed in the area compared to Issyk-Kul. This could be a reason why shelterbelts are rarely found in the village. According to the respondents, shelterbelts were not common in the area in the past. Generally, rules related to establishing shelterbelts are interpreted rather restrictively in Kyzyl Aiyl, with half of the respondents in the village stating that it is forbidden to plant them. Two interviewees stated that a permission by the Aiyl Okmotu is needed, while the Aiyl Okmotu reported that planting shelterbelts in the village is completely forbidden.

The presented examples show that the adoption or rejection of shelterbelts cannot be reduced to a single dominating factor. Instead, site-specific conditions, in particular climatic conditions, the level of knowledge of households, as well as the rules set by the Aiyl Okmotu profoundly shape the perception of and attitude towards shelterbelts. In Bokonbaevo, where a tradition of making effective use of shelterbelts exists and strong winds and a lack of precipitation prevail, farmers are more likely to adopt shelterbelt systems. In Kyzyl Aiyl, in contrast, climatic conditions do not necessarily underline the need to protect fields from strong wind, and a relative lack of knowledge about the benefits of shelterbelts possibly explains their negative perception. In both cases, the rules set by local authorities are decisive for the adoption of shelterbelts.

\section{Conclusions}

In order to better understand which factors promote or inhibit farmers' pro-environmental behavior-in our case, the planting and maintenance of protective tree shelterbelts-we selected two case study regions to identify similarities and differences in two geographical locations. The conceptual framework of the study, which focused on showing the linkages and interaction between extrinsic 
and intrinsic variables as well as the missing influence of the intervening variable of extension in the decision-making process of farmers was helpful to understand the conditions for adoption in a more holistic way. The framework provided a useful lens guiding the development of guiding questions, semi-structured interviews, and observations during field visits.

The results on household characteristics showed a high dependency on local natural resources for agriculture, in particular on water utilized through irrigation techniques. Under changing climatic conditions, water use efficiency will be decisive for the resilience of the agro-ecological systems. Currently, however, the windbreak effect and potentials for more efficient use of water are not a major concern of farmers. There are plausible reasons why farmers are currently reluctant to invest time and resources in the re-establishing of shelterbelts (such as small and scattered field sizes combined with the concern about conflicts with neighbouring farmers). It is striking, though, that only one respondent expressed plans to plant shelterbelts when asked about such plans.

A strategy to increase the adoption of shelterbelts (in order to take advantage of their ecosystem services) is to put stronger emphasis in argumentation on those benefits that are ranked highest by the farmers. These include the provision of construction material, firewood, fences, and the like. There are many synergies between the provisioning and regulating ecosystem services of shelterbelts, which can be best communicated at demonstration sites managed by local farmers themselves under supervision and support of extension workers. This requires willingness from the side of the farmers and support from regional agricultural extension organizations that have so far been rather inactive in the promotion of agroforestry. A further strategy is to broaden the focus of agroforestry extension to include not only shelterbelts but to integrate more prominently the planting of fruit trees into extension strategies as a way to generate additional income and to diversify the basis of livelihoods.

Important obstacles identified during field studies were the role of and rule setting by the local governments (Aiyl Okmotu). The interpretations and knowledge of the national legal framework varied considerably from village to village. Therefore, working together and with the support of local governments is important. Since the usefulness of shelterbelts was clearly demonstrated for the large-scale cooperative farms during Soviet times, one way to overcome the obstacle of small field sizes would be to promote the adoption of cooperative arrangements to set up joint shelterbelt systems covering larger areas of land. This would also require institutional support to show how modern cooperative arrangements can function in the Kyrgyz context.

For any intervention to encourage the planting of shelterbelts, be it by the state, NGOs or other actors, a sound understanding of both intrinsic and extrinsic factors and their interlinkages is needed. While the extrinsic factors are usually better known and more obvious, the intrinsic factors (knowledge, perceptions, and attitudes) frequently remain unclear. The research showed that by applying the framework, no single dominant factor, but a rich multifaceted picture of variables can be identified. In our particular case, the interplay between past experiences, lack of knowledge, the lack of encouragement of local administrative bodies and non-consistent interpretation of legal rules creates a situation that does not promote environmentally friendly behavior of farmers. Thus, communication and extension as an influencing variable needs to be supported by changes towards an improved vertical integrity in public administration.

The results of this study are relevant in the broader global context, where adopting an ecosystem approach to agro-ecological systems, ecosystem restoration, and more specifically planting trees is getting increasing attention and support from many sides. Besides providing new insights into the adoption of tree shelterbelts in Kyrgyzstan, this research highlights the need to study and take farmers' concerns seriously when developing strategies to promote environmentally friendly behavior. The promotion of sustainable land use systems requires the right institutional frameworks, proper communication, and extension work e.g., through demonstration sites, best practice examples, but also a serious engagement with farmer concerns. Understanding the manifold factors affecting adoption or non-adoption is the key to successful policy development. 
Author Contributions: Conceptualization was developed by all four authors; methodology was developed by M.W., D.R. and M.S.; formal analysis by D.R.; investigation by D.R.; resources by N.T.; draft preparation and editing by D.R., M.W., M.S., and N.T.; visualization by D.R., N.T. and map design by M.S.; supervision by M.S. and M.W.; project administration by M.S. and M.W.; funding acquisition by M.W. and N.T. All authors have read and agreed to the published version of the manuscript.

Funding: This research was funded by the German Ministry of Education and Research (BMBF). The project was entitled eAGROFORST-Food security and livelihood improvement through agroforestry in Central Asia (grant number 01DK17019).

Acknowledgments: We are grateful for the support of Begaiym Emileva and the other team members of World Agroforestry (ICRAF) for their support during field research. Many thanks go to Kara Canlas Lorraine for inspiring discussions in Kyrgyzstan.

Conflicts of Interest: The authors have no conflict of interest.

\section{References}

1. Norris, K. Agriculture and biodiversity conservation: Opportunity knocks. Conserv. Lett. 2008, 1, 2-11. [CrossRef]

2. Intergovernmental Panel on Climate Change. Climate Change 2014: Impacts, Adaptation and Vulnerability; Working group II contribution to the fifth assessment report of the Intergovernmental Panel on Climate Change; Cambridge University Press: New York, NY, USA, 2014.

3. Le, Q.B.; Nkonya, E.; Mirzabaev, A. Biomass productivity-based mapping of global land degradation hotspots. In Economics of Land Degradation and Improvement: A Global Assessment for Sustainable Development; Nkonya, E., Mirzabaev, A., von Braun, J., Eds.; Springer: London, UK, 2016; pp. 55-84.

4. Delgado, J.A.; Groffman, P.M.; Nearing, M.A.; Goddard, T.; Reicosky, D.; Lal, R.; Kitchen, N.R.; Rice, C.W.; Towery, D.; Salon, P. Conservation practices to mitigate and adapt to climate change. J. Soil Water Conserv. 2011, 66, 118A-129A. [CrossRef]

5. Altieri, M.A.; Nicholls, C.I.; Henao, A.; Lana, M.A. Agroecology and the design of climate change-resilient farming systems. Agron. Sustain. Dev. 2015, 35, 869-890. [CrossRef]

6. Mbow, C.; Van Noordwijk, M.; Luedeling, E.; Neufeldt, H.; Minang, P.A.; Kowero, G. Agroforestry solutions to address food security and climate change challenges in Africa. Curr. Opin. Environ. Sustain. 2014, 6, 61-67. [CrossRef]

7. Wilson, M.; Lovell, S. Agroforestry-The Next Step in Sustainable and Resilient Agriculture. Sustainability 2016, 8, 574. [CrossRef]

8. Feder, G.; O'Mara, G.T. Farm Size and the Diffusion of Green Revolution Technology. Econ. Dev. Cult. Change 1981, 30, 59-76. [CrossRef]

9. Feder, G.; Umali, D.L. The adoption of agricultural innovations: A review. Technol. Forecast. Soc. Change 1993, 43, 215-239. [CrossRef]

10. Isham, J. The effect of social capital on fertiliser adoption: Evidence from rural Tanzania. J. Afr. Econ. 2002, 11,39-60. [CrossRef]

11. Padel, S. Conversion to organic farming: A typical example of the diffusion of an innovation? Sociol. Rural 2001, 41, 40-61. [CrossRef]

12. Läpple, D.; Rensburg, T.V. Adoption of organic farming: Are there differences between early and late adoption? Ecol. Econ. 2011, 70, 1406-1414. [CrossRef]

13. Teklewold, H.; Kassie, M.; Shiferaw, B. Adoption of Multiple Sustainable Agricultural Practices in Rural Ethiopia. J. Agric. Econ. 2013, 64, 597-623. [CrossRef]

14. Thevs, N.; Strenge, E.; Aliev, K.; Eraaliev, M.; Lang, P.; Baibagysov, A.; Xu, J. Tree shelterbelts as an element to improve water resource management in Central Asia. Water 2017, 9, 842. [CrossRef]

15. Kort, J. Benefits of windbreaks to field and forage crops. Agric. Ecosyst. Environ. 1988, 22, 165-190. [CrossRef]

16. Alemu, M.M. Ecological Benefits of Trees as Windbreaks and Shelterbelts. Int. J. Ecosyst. 2016, 6, 10-13. [CrossRef]

17. Djanibekov, U.; Dzhakypbekova, K.; Chamberlain, J.; Weyerhaeuser, H.; Zomer, R.; Villamor, G.B.; Xu, J. Agroforestry for Landscape Restoration and Livelihood Development in Central Asia; ICRAF Working Paper 186; World Agroforestry Centre East and Central Asia: Kunming, China, 2015. 
18. Djalilov, B.M.; Khamzina, A.; Hornidge, A.K.; Lamers, J.P.A. Exploring constraints and incentives for the adoption of agroforestry practices on degraded cropland in Uzbekistan. J. Environ. Plan. Manag. 2016, 59, 142-162. [CrossRef]

19. United Nations; Food and Agriculture Organization of the United Nations. Forest Landscape Restoration in the Caucasus and Central Asia; Timber and Forest Discussion Paper 72; UNECE/FAO: Geneva, Switzerland, 2019; Available online: http://www.unece.org/fileadmin/DAM/timber/publications/DP-72-flr-cca-en.pdf (accessed on 23 November 2019).

20. Juldashev, U.; Messerli, S. Trees and Agriculture in the Walnut Fruit Forests of Southern Kyrgyzstan: Current Situation and the Potential for Agroforestry; Programme Document of Intercooperation; LES-IC: Bishkek, Kyrgyzstan, 2000; pp. 1-77.

21. Petrick, M.; Pomfret, R. Agricultural Policies in Kazakhstan; Discussion Paper No. 155; Leibniz Institute of Agricultural Development in Transition Economies (IAMO): Halle, Germany, 2017.

22. Djanibekov, U.; Villamor, G.; Dzhakypbekova, K.; Chamberlain, J.; Xu, J. Adoption of Sustainable Land Uses in Post-Soviet Central Asia: The Case for Agroforestry. Sustainability 2016, 8, 1030. [CrossRef]

23. Meijer, S.S.; Catacutan, D.; Ajayi, O.C.; Sileshi, G.W.; Nieuwenhuis, M. The role of knowledge, attitudes and perceptions in the uptake of agricultural and agroforestry innovations among smallholder farmers in sub-Saharan Africa. Int. J. Agric. Sustain. 2014, 13, 40-54. [CrossRef]

24. National Statistical Committee of the Kyrgyz Republic. Brief Statistical Handbook 2017-2018; National Statistical Committee of the Kyrgyz Republic: Bishkek, Kyrgyzstan, 2019.

25. Mogilevskii, R.; Abdrazakova, N.; Bolotbekova, A.; Chalbasova, S.; Dzhumaeva, S.; Tilekeyev, K.; Balmann, A.; Brosig, S.; Glauben, T.; Herzfeld, T.; et al. The Outcomes of 25 Years of Agricultural Reforms in Kyrgyzstan; Discussion Paper No. 162; Leibniz Institute of Agricultural Development in Transition Economies (IAMO): Halle, Germany, 2017.

26. Undeland, A.; Mitchell, A.M. Kyrgyz Republic_Communities Forests and Pastures; World Bank: Washington, DC, USA, 2015.

27. Food and Agriculture Organization of the United Nations. Kyrgyz Republic-Agricultural Land (\% of Land Area). Available online: https://data.worldbank.org/indicator/AG.LND.AGRI.ZS?locations=KG (accessed on 7 June 2019).

28. Mirzabaev, A.; Goedecke, J.; Dubovyk, O.; Djanibekov, U.; Le, Q.B.; Aw-Hassan, A. Economics of Land Degradation in Central Asia. In Economics of Land Degradation and Improvement-A Global Assessment for Sustainable Development; Nkonya, E., Mirzabaev, A., von Braun, J., Eds.; Springer: Cham, Switzerland, 2016; pp. 261-290.

29. Bloch, P.C.; Delehanty, J.M.; Roth, M.J. Land and Agrarian Reform in the Kyrgyz Republic; LTC Research Paper 128; Land Tenure Center: Madison, WI, USA, 1996.

30. Lerman, Z.; Sedik, D. Agrarian Reform in Kyrgyzstan: Achievements and the Unfinished Agenda; Policy Studies on Rural Transition No. 2009-1; FAO: Budapest, Hungary, 2009.

31. Chyngojoev, A.; Surappaeva, B.; Altrell, D. Integrated Assessment of Natural Resources of Kyrgyzstan 2008-2010; FAO: Bishkek, Kyrgyzstan, 2010.

32. Baetov, R. Lake Issyk Kul. Lake Basin Management Initiative Experience and Lessons Learned Brief. In Proceedings of the Lake Basin Management Initiative Regional Workshop for Europe, Central Asia and the Americas, Colchester, VT, USA, 18-21 June 2003; Available online: http://www.worldlakes.org/uploads/ issyk-kul_30sep04.pdf (accessed on 15 November 2019).

33. Giralt, S.; Julià, R.; Klerkx, J.; Riera, S.; Leroy, S.; Buchaca, T.; Catalan, J.; Batist, M.; Beck, C.; Bobrov, V.; et al. 1000-Year Environmental History of Lake Issyk-Kul. In Dying and Dead Seas Climatic Versus Anthropic Causes; NATO Science Series: IV: Earth and Environmental Sciences; Nihoul, J.C.J., Zavialov, P.O., Micklin, P.P., Eds.; Springer: Dordrecht, The Netherlands, 2004; Volume 36, pp. 228-253.

34. Ilyasov, S.; Zabenko, O.; Gaydamak, N.; Kirilenko, A.; Myrsaliev, N.; Shevchenko, V.; Penkina, L. Climate Profile of the Kyrgyz Republic; The State Agency for Environmental Protection and Forestry under the Government of the Kyrgyz Republic and The United Nations Development Programme: Bishkek, Kyrgyzstan, 2013.

35. National Statistical Committee of the Kyrgyz Republic. Resident Population as of the Beginning of the Year; National Statistical Committee of the Kyrgyz Republic: Bishkek, Kyrgyzstan, 2019; Available online: http://www.stat.kg/en/opendata/category/39/ (accessed on 8 July 2019). 
36. Climate-Data. Klima: Kirgisistan. Available online: https://de.climate-data.org/asien/kirgisistan-237/ (accessed on 26 August 2019).

37. Dzhakypbekova, K. A Financial Valuation of Agroforestry Practices on the Irrigated Farmlands in Kyrgyzstan. Master's Thesis, Rheinische Friedrich-Wilhelms-Universität, Bonn, Germany, January 2018.

38. Romer, B. Agroforestry in Tajikistan: Overview of Current Situation, the Potential, and the Influencing Factors of Agroforestry Systems; CAMP_Central Asian Montain Partnership: Dushanbe, Tajikistan, 2005; pp. 1-37.

39. Mercer, D.E. Adoption of agroforestry innovations in the tropics: A review. Agrofor. Syst. 2004, 61, 311-328. [CrossRef]

40. Pattanayak, S.K.; Evan Mercer, D.; Sills, E.; Yang, J.C. Taking stock of agroforestry adoption studies. Agrofor. Syst. 2003, 57, 173-186. [CrossRef]

41. Graves, A.R.; Burgess, P.J.; Liagre, F.; Pisanelli, A.; Paris, P.; Moreno, G.; Bellido, M.; Mayus, M.; Postma, M.; Schindler, B.; et al. Farmer Perceptions of Silvoarable Systems in Seven European Countries. In Agroforestry in Europe: Current Status and Future Prospects; Rigueiro-Rodróguez, A., McAdam, J., Mosquera-Losada, M.R., Eds.; Springer: Dordrecht, The Netherlands, 2009; Volume 6, pp. 67-86.

42. Rois-Díaz, M.; Lovric, N.; Lovric, M.; Ferreiro-Domínguez, N.; Mosquera-Losada, M.R.; den Herder, M.; Graves, A.; Palma, J.H.N.; Paulo, J.A.; Pisanelli, A.; et al. Farmers' reasoning behind the uptake of agroforestry practices: Evidence from multiple case-studies across Europe. Agrofor. Syst. 2018, 92, 811-828. [CrossRef]

43. Dahlquist, R.M.; Whelan, M.; Winowiecki, L.; Polidoro, B.; Candela, S.; Harvey, C.; Wulfhorst, J.D.; Mcdaniel, P.; Bosque-Pérez, N.A. Incorporating livelihoods in biodiversity conservation: A case study of cacao agroforestry systems in Talamanca, Costa Rica. Biodivers. Conserv. 2007, 16, 2311-2333. [CrossRef]

44. Kiptot, E.; Hebinck, P.; Franzel, S.; Richards, P. Adopters, testers or pseudo-adopters? Dynamics of the use of improved tree fallows by farmers in western Kenya. Agric. Syst. 2007, 94, 509-519. [CrossRef]

45. Garrity, D.P.; Bayala, J. Zinder: Farmer-managed natural regeneration of Sahelian parklands in Niger. In Sustainable Development Through Trees on Farms: Agroforestry in Its Fifth Decade; Van Noordwijk, M., Ed.; World Agroforestry (ICRAF) Southeast Asia Regional Program: Bogor, Indonesia, 2019; pp. 151-172.

46. Allen, J.A. Homestead tree planting in two rural Swazi communities. Agrofor. Syst. 1990, 11, 11-22. [CrossRef]

47. Phiri, D.; Franzel, S.; Mafongoya, P.; Jere, I.; Katanga, R.; Phiri, S. Who is using the new technology? The association of wealth status and gender with the planting of improved tree fallows in Eastern Province, Zambia. Agric. Syst. 2004, 79, 131-144. [CrossRef]

48. Sileshi, G.; Kuntashula, E.; Matakala, P.; Nkunika, P. Farmers' perceptions of tree mortality, pests and pest management practices in agroforestry in Malawi, Mozambique and Zambia. Agrofor. Syst. 2008, 72, 87-101. [CrossRef]

49. Rogers, E.M. Diffusion of Innovations, 4th ed.; Free Press: New York, NY, USA, 1995.

50. Ajzen, I. The theory of planned behavior. Organ. Behav. Hum. Decis. Process. 1991, 50, 179-211. [CrossRef]

51. Lynne, G.D.; Franklin Casey, C.; Hodges, A.; Rahmani, M. Conservation technology adoption decisions and the theory of planned behavior. J. Econ. Psychol. 1995, 16, 581-598. [CrossRef]

52. Sharifzadeh, M.; Zamani, G.H.; Khalili, D.; Karami, E. Agricultural Climate Information Use: An Application of the Planned Behavior Theory. J. Agric. Sci. Technol. 2012, 14, 479-492.

53. Simin, M.T.; Janković, D. Applicability of diffusion of innovation theory in organic agriculture. Econ. Agric. 2014, 61, 517-529. [CrossRef]

54. Perles, M.D. Potential Effects of Agroforestry on Agricultural Landscapes in Central Asia Using Remote Sensing and Geo-Statistical Methods. Master's Thesis, Eberswalde University for Sustainable Development, University of Applied Sciences, Eberswalde, Germany, July 2018.

55. Subedi, S. Measurement of Age-Biomass Relationship of Poplar in Agroforestry in Kyrgyzstan. Master's Thesis, Ernst Moritz Arndt University, Greifswald, Germany, August 2016.

56. Thevs, N.; Emileva, B.; Canlas, K.L. The Two Sides of Rural-Urban Migration. Rural 21. 12 December 2018, pp. 29-31. Available online: https://www.rural21.com/uploads/media/rural2018_04-S29-31.pdf (accessed on 23 November 2019).

57. Himshikha. Three decades of Agroforestry and its Socioeconomics. Int. J. Agric. Sci. Res. 2016, 6, $283-300$.

58. Montambault, J.R.; Alavalapati, J.R.R. Socioeconomic research in Agroforestry: A decade in review. Agrofor. Syst. 2005, 65, 151-161. [CrossRef] 
59. Jones, K.D. Land privatization and conflict in Central Asia: Is Kyrgyzstan a model? In The Tracks of Tamerlane: Central Asia's Paths to the 21st Century; Burghart, D.L., Sabonis-Helf, T., Eds.; Center for Technology and National Security Policy: Washington, DC, USA, 2003; pp. 259-273.

60. Steimann, B. Making a Living in Uncertainty: Agro-Pastoral Livelihoods and Institutional Transformations in Post-Socialist Rural Kyrgyzstan; Müller-Böker, U., Ed.; Human Geography Series; University of Zurich: Zurich, Switzerland, 2011; Volume 26.

61. Djanibekov, U. A coevolutionary perspective on the adoption of sustainable land use practices: The case of the Amu Darya River lowlands, Uzbekistan. In Evolutionary Governance Theory; Beunen, R., van Assche, K., Duineveld, M., Eds.; Springer: Berlin/Heidelberg, Germany, 2015; pp. 233-245.

(C) 2020 by the authors. Licensee MDPI, Basel, Switzerland. This article is an open access article distributed under the terms and conditions of the Creative Commons Attribution (CC BY) license (http://creativecommons.org/licenses/by/4.0/). 